\title{
KOMPOSISI GERAK PADA PERTUNJUKAN KESENIAN TARI PETUK DI DESA SADE KABUPATEN LOMBOK TENGAH
}

\author{
Nur Aini Fajrianti ${ }^{1}$, Yuspianal Imtihan ${ }^{2}$ \\ Universitas Hamzanwadi ${ }^{1,2}$ \\ Fajrianti935@gmail.com ${ }^{1}$
}

\begin{abstract}
ABSTRAK
Penelitian ini bertujuan untuk mendeskripsikan komposisi gerak dan bentuk penyajian Tari Petuk di Desa Sade Kabupaten Lombok Tengah. Pendekatan yang digunakan dalam penelitian ini adalah deskriptif kualitatif. objek dalam penelitian ini adalah Tari Petuk yang meliputi komposisi gerak dan bentuk penyajian. Pengumpulan data dilakukan dengan cara 1) observasi, 2) wawancara, dan 3) dokumentasi. Analisis data dilakukan dengan 1) reduksi data, 2) penyajian data, dan 3) kesimpulan. Untuk memeriksa keabsahan data dilakukan dengan teknik validitas data yaitu dengan teknik triangulasi. Hasil penelitian ditemukan tentang: 1) komposisi gerak Tari Petuk, yang meliputi a) unsur-unsur gerak, b) jenis gerak, dan c) watak gerak. 2) bentuk penyajian terdiri dari a) pendukung, b) iringan, c) kostum/busana, d) properti, e) tata rias, f) lighting atau tata lampu, dan g) tempat pertunjukan. Dari hasil penelitian dapat disimpulkan bahwa kesenian Tari Petuk merupakan kesenian tari yang memerlukan banyak unsur dan jenis gerakan. Dalam pertunjukan Tari Petuk juga memerlukan beberapa hal seperti musik, busana, tata rias.
\end{abstract}

Kata Kunci: Komposisi Gerak, Bentuk Penyajian, Tari Petuk.

\begin{abstract}
This research aims to describe motion composition and presentation formation of Petuk dance at Sade Village Central Lombok.An approach used on this research is descriptif qualitative. The object is Petuk dance whichis cover motion composition and presentation formation. The technique for collecting all data by using 1) observation, 2) interview, and 3) documentation. The data is analyzed by 1) data reduction, 2) data presentation, and 3) Conclusion. While for checking data validity, this research used triangulation technique. This research shows some results, they are 1) motion composition include a) motion elements, b) kinds of motion, c) motion caracter. 2) presentation of petuk dance consist of a) petuk dance attribute, $b$ ) clothing, c) accompaniment, d) and property, e) decoration, $f$ ) lighting, g) place for presentation. From the results of the study it can be concluded that Petuk Dance is a dance art that requires many elements and types of movements. In Petuk Dance performances also require things like music, clothing, make-up.
\end{abstract}

Keywords: Motion Composition, Presentation Formation, Petuk Dance. 


\section{PENDAHULUAN}

Desa Sade terletak di Desa Rembitan, Kecamatan Pujut, Lombok Tengah, Nusa Tenggara Barat (NTB). Desa ini dikenal sebagai destinasi wisata karena penduduknya masih menjaga keutuhan budaya dan pola hidup yang diwariskan leluhur mereka. Seperti bentuk bangunan, adat istiadat, tari-tarian, permainan musik, gaya berpakaian yang masih tradisional dan masih dilestarikan hingga dewasa ini. Karya tari merupakan satu diantara seni-seni yang mendapat perhatian cukup besar dari masyarakat di Desa Sade. Salah satunya adalah Tari Petuk.

Tari Petuk ditarikan oleh satu atau dua orang anak laki-laki. Wajahnya dirias dengan bedak tebal dengan alis serta kumis buatan yang tebal juga. Tari petuk dilakukan dengan lincah dan memukau, mengikuti irama musik dengan tempo yang relatif cepat. Perubahan gerak dari ragam satu ke ragam selanjutnya sangat cepat, medkipun demikian ragam Tari Petuk memiliki komposisi yang sederhana. Komposisi inilah yang mengatur bagian demi bagian sehingga satu gerak dengan gerak lainnya saling berhubungan dan secara bersama membentuk kesatuan yang utuh. Sebagaimana yang dikemukakan oleh Wulandari (2015) "Komposisi adalah meletakkan, mengatur, dan menata bagian-bagian sedemikian rupa sehingga satu dengan yang lainnya saling jalin menjalin membentuk satu kesatuan yang utuh".

Tari Pentuk ini juga memiliki karakteristik yang khas dalam bentuk komposisi geraknya. Karakteristik ini ditunjukkan secara simbolik. Karena tari petuk lebih menekankan pada kejenakaan, tapi tidak melepaskan pakem dari tarian tradisional Sasak pada umumnya.

Bentuk pertunjukan adalah adalah wujud dalam menyampaikan suatu pergelaran/pertunjukan kesenian tari secara menyeluruh meliputi unsur-unsur atau elemen pokok dan pendukung tari. Menurut Sepiolita (2017) Bentuk pertunjukan adalah segala sesuatu yang dipertunjukkan atau ditampilkan dari awal sampai akhir untuk dapat diamati atau dilihat, dan didalamnya mengandung unsur-unsur nilai keindahan yang disampaikan oleh pencipta kepada penikmat.

Berdasarkan hal tersebut tulisan ini membahas kajian tentang komposisi gerak dan bentuk pertunjukan Tari Petuk di Desa Sade Kabupaten Lombok Tengah.

\section{METODE PENELITIAN}

Metode yang digunakan dalam penelitian ini adalah metode penelitian kualitatif yang bersifat deskriptif. Penelitian ini berkeinginan untuk mengungkapkan data atau informasi mengenai komposisi gerak dan bentuk pertunjukan Tari Petuk. Menurut Sugiyono metode penelitian kualitatif adalah metode penelitian yang berlandaskan pada filsafat postpositivisme, digunakan untuk meneliti pada kondisi alamiah, (sebagai lawannya adalah eksperimen) peneliti sendiri adalah sebagai instrumen kunci, teknik pengumpulan data dilakukan secara tringulasi (gabungan), analisis data bersifat induktif/kualitatif, dan hasil penelitian lebih menekankan pada makna dari pada generalisasi (Sugiyono, 2013). 


\section{HASIL DAN PEMBAHASAN Komposisi Gerak Tari}

Komposisi gerak Tari Petuk yang akan dibahas meliputi unsurunsur gerak, jenis gerak dan watak gerak:

\section{Unsur-unsur Gerak}

Berdasarkan pengamatan peneliti tidak semua tarian Petuk di tarikan dengan gerakan bebas oleh setiap penarinya akan tetapi ada gerakan-gerakan yang sama yang dilakukan oleh setiap penari. Gerakan yang sama yang terdapat dalam Tari Petuk tersebut dapat dilihat pada unsur-unsur gerak Tari Petuk, yang meliputi gerak kepala, gerak tangan, gerak badan dan gerak kaki. Untuk memudahkan peneliti dalam menguraikan unsur-unsur gerak Tari Petuk, maka gerak dibagi menjadi 2 yaitu gerak sebagai sikap dan gerak sebagai pelaksana.

\section{Gerak Kepala}

1. Sikap. Dalam Tari Petuk terdapat gerakan menganggukkan kepala ke bawah kemudian di angkat ke atas dengan cepat. Dalam buku YSB Pulayakendase (2010) gerakan ini dinamakan Angguk Anjuk. Angguk Anjuk adalah mengangguk cepat yang tertahan (disentak); a) dalam Tari Petuk terdapat gerakan kepala 90 derajat menghadap ke kanan. Gerakan ini dilakukan dengan memutar halus kepala 90 derajat menghadap ke kanan. Pada buku YSB Pulayakendase (2010) gerakan ini diamakan Ngelawas Kanan. Ngelaws kanan adalah posisi kepala 90 derajat menghadap ke kanan, b) dalam Tari Petuk terdapat proses gerak menoleh dengan posisi kepala 90 derajat menghadap ke kiri. Gerakan ini dilakukan dengan memutar halus kepala 90 derajat menghadap ke kiri. Pada buku YSB Pelayakendase (2010) gerakan seperti ini dinamakan Ngelewas kiri. Ngelawas Kiri adalah proses gerak menoleh dengan posisi kepala 90 derajat menghadap ke kiri.

2. Gerak Pelaksana; a) pada tari Petuk terdapat gerakan dagu di majukan ke depan dan kepala seolah menarik dagu ke belakang. Pada buku YSB Pulayakendase (2010) gerakan ini dinamakan Nyetuk. Nyetuk adalah gerakan dagu ke muka ke belakang, b) pada Tari Petuk terdapat gerak kepala dengan memfokuskan putaran dagu seolah menulis angka delapan ke kiri atau ke kanan. Dalam buku YSB Pulayakendase (2010) gerakan ini dinamakan Tolehan. Tolehan adalah proses gerak dari sikap kepala tegak lurus, kemudian leher digerakkan atau diputar (menoleh) ke kanan atau ke kiri, c) dalam Tari Petuk terdapat gerakan kepala 90 derajat menghadap ke kanan. Gerakan ini dilakukan dengan memutar halus kepala 90 derajat menghadap ke kanan. Pada buku YSB Pulayakendase (2010) ini dinamakan Ngelawas Kanan. Ngelawas kanan adalah gerakan kepala 90 derajat menghadap ke kanan, d) dalam tari petuk terdapat proses gerak menoleh dengan posisi kepala 90 derajat menghadap ke kiri. Gerakan ini dilakukan dengan memutar halus kepala 90 derajat menghadap ke kiri. Pada buku YSB Pelayakendase (2010) gerakan seperti ini dinamakan Ngelawas kiri. Ngelawas kiri adalah proses 
gerak menoleh dengan posisi kepala 90 derajat menghadap ke kiri

\section{Gerak Tangan}

1. Sikap; a) pada gerakan Tari Petuk terdapat gerakan mengangkat tangan kanan sejajar dengan bahu dengan posisi ibu jari menempel pada telapak tangan, dan keempat jari berdiri dengan posisi jari-jari rapat. Pada buku YSB Pulayakendase (2010) gerakan ini dinamakan mentang kanan. Mentang kanan adalah tangan kanan dijulurkan ke samping kanan sejajar dengan bahu, b) pada Tari Petuk terdapat gerakan mengangkat tangan kiri jejajar dengan bahu dengan posisi ibu jari menempel pada telapak tangan, dan keempat jari berdiri dengan posisi jari-jari rapat. Pada buku YSB Pulayakendase (2010) gerakan ini dinamakan Mentang Kiri. Mentang kiri adalah tangan kiri dijulurkan ke samping kiri sejajar dengan bahu, c) gerakan ini meupakan salah satu ragam gerak Tari Petuk. Ragam gerak dalam tarian Petuk ini merupakan bentuk penghormatan kepada para wisatawan, baik wisatawan lokal maupun mancanegara. Gerakan ini dilakukan dengan menundukkan kepala sambil merapatkan telapak tangan kemudian dipisahkan dan diturunkan perlahan. Setelah itu penari kembali ke belakang panggung. Dalam buku YSB Pulayakendase (2010) gerakan ini dinamakan Nyakep. Nyakep adalah kedua telapak tangan dicakupkan di depan dada.

2. Gerak Pelaksana; a) pada tari Petuk terdapat gerakan tangan dengan memutar pergelangan tangan searah dengan arah jarum jam. Dalam buku YSB Pulayakendase (2010) gerakan ini dinamakan Ngikel. Ngikel adalah gerakan pergelangan tangan memutar ke dalam, b) pada Tari Petuk terdapat gerakan tangan dengan memutar pergelangan tangan berlawanan arah jarum jam. Dalam buku YSB Pulayakendase (2010) gerakan ini dinamakan Motes. Motes adalah gerakan pergelangan tangan memutar ke luar., c) pada Tari Petuk terdapat gerakan mengayunkan telapak tangan kanan dan kiri ke atas dan ke bawah secara bergantian. Dalam YSB Pulayakendase (2010) gerakan ini dinamakan Nyakaq. Nyakaq adalah gerakan kedua telapak tangan turun naik bergantian berkesinambungan.

\section{Gerak Badan}

1. Sikap; a) pada tari petuk terdapat posisi badan tegak dan kedua lutut ditekuk membuka ke samping. Dalam buku YSB Pulayakendase (2010) gerakan ini dinamakan Ndegeg. Ndegeg atau Tegak adalah sikap badan tegak lurus dengan kunci utama menarik nafas, maka dengan sendirimya anggota badan yang lain akan terbawa, seperti halnya dada maju, tulang belakang tegak lurus, dan tulang belikat menjadi rata, b) pada gerak Tari Petuk terdapat gerakan menggerakkan seluruh tubuh ke samping kiri atau kanan tanpa mengangkat kaki. Dalam buku YSB Pulayakendase (2010) gerakan ini dinamakan Miring. Miring adalah sikap badan tegak lurus (tidak membungkuk) diputar menghadap ke samping kanan atau kiri. 
2. Gerak; a) pada tari petuk terdapat gerakan tumit kaki dibuka ke samping dan salah satu telapak kaki dibuka, kemudian badan di angkat dengan bertumpu pada tumit. Dalam YSB Pulayakendase (2010) gerakan ini dinamakan Tindak Baris. Tindak Baris adalah badan tegak, diangkat dengan angkatan tumit yang bertumpu, b) dalam tari petuk terdapat gerakan badan bergerak ke kiri dan ke kanan secara bergantian dengan badan tegak lurus. Dalam YSB Pulayakendase (2010) gerakan ini dinamakan Yeliuk. Yaliuk adalah badan bergerak ke kiri atau ke kanan.

\section{Gerak Kaki}

1. Sikap; a) pada tari petuk terdapat gerakan tari dengan posisi telapak kaki dibuka kesamping kemudian badan agak diturunkan sampai posisi kaki membentuk hurup $\mathrm{O}$. Dalam buku YSP Pulayakendase (2010) gerakan ini dinamakan Ngencek Lembut. Ngencek Lembut adalah sikap telapak kaki tepah engkang dan tungkai berbentuk $\mathrm{O}$, b) pada tari petuk terdapat gerakan dengan posisi kaki dibuka dan bergeser secara bergantian ke samping kanan maupun ke samping kiri , kemudian telapak kaki kiri dan kanan dibuka secara bergantian untuk dijadikan sebagai tumpuan. Dalam YSB Pulayakendase (2010) gerakan ini dinamakan Bedeser. Bedeser adalah gerakan begeser ke samping kanan dan ke kiri bertumpu pada tumit, c) pada tari petuk terdapat gerakan dengan posisi telapak kaki kanan di depan telapak kaki kiri dan kaki kiri dibelakang kaki kanan. Jarak antara kaki kiri dan kaki kanan berjarak dua kali telapak kaki. Posisi badan tegak dan bahu di angkat. Dalam buku YSP Pulayakendase (2010) gerakan ini dinamakan Surut Ngenjek. Surut Ngenjek adalah surut dengan cepat diimbangan dengan gerakan bahu dan badan tegak.

2. Gerak; a) pada tari petuk terdapat gerakan melangkahkan telapak kaki kiri dan telapak kaki kanan ke depan secara bergantian dengan jarak antara kaki kiri dan kaki kanan dua kali telapak kaki. Posisi badan tegak dan diturunkan sedikit bertumpu pada tumit. Dalam buku YSB Pulayakendase (2010) gerakan ini dinamakan Ngelangkah Maju. Ngelangkah Maju adalah proses gerak kaki berjalan melangkah kedepan, b) pada tari petuk terdapat gerakan melangkahkan telapak kaki kiri dan telapak kaki kanan ke belakang secara bergantian dengan jarak antara kaki kiri dan kaki kanan dua kali telapak kaki. Posisi badan tegak diturunkan sedikit dan bertumpu pada tumit. Dalam buku YSB Pulayakendase (2010) gerakan ini dinamakan Ngelangkah Mundur. Ngelangkah Mundur adalah proses gerak kaki berjalan melangkah kebelakang, c) pada tari petuk terdapat gerak seperrti lari dengan cepat ke kiri, ke kanan, maju mundur dengan posisi kaki membuka dan jinjit. Dalam buku YSB Pulayakendase (2010) gerakan ini di sebut Srisig. Srisig adalah berpindah tempat kekanan, kekiri, maju mundur atau berputar, dengan berlari kecil dan jinjit, tubuh agak merendah.

Tabel 1 Rangkuman dari penjabaran gerak sebagai sikap 


\begin{tabular}{ccc}
\hline No & Gerak & Jumlah \\
\hline 1 & Kepala & 3 \\
\hline 2 & Tangan & 3 \\
\hline 3 & Badan & 2 \\
\hline 4 & Kaki & 3 \\
\hline
\end{tabular}

Tabel 2 Rangkuman dari penjabaran gerak sebagai pelaksana

\begin{tabular}{ccc}
\hline No & Gerak & Jumlah \\
\hline 1 & Kepala & 4 \\
\hline 2 & Tangan & 3 \\
\hline 3 & Badan & 2 \\
\hline 4 & Kaki & 3 \\
\hline
\end{tabular}

Dari hasil analisis yang telah tertulis pada rangkuman di atas, maka peneliti menyimpulkan bahwa bentuk Tari Petuk menggunakan bermacam-macam bagian gerak, baik bagian gerak sebagai sikap, maupun gerak sebagai pelaksana terdiri dari 23 bagian gerak.

\section{Jenis Gerak}

Jenis gerak dibagi menjadi 2 yaitu gerak murni dan gerak maknawi:

1. Gerak murni. Gerak murni adalah gerak yang digarap sekedar untuk mendapatkan bentuk artistik dan tidak dimaksudkan untuk menggambarkan sesuatu. Beberapa gerak murni yang terdapat dalam Tari Petuk adalah angguk anjuk, nglewas kanan, nglewas kiri, nyetuk, tolehan, nglewas kanan, nglewas kiri, mentang kanan, mentang kiri, ngikel, motes, nyakaq, ndgeg, miring, tindak baris, nyaliuk, ngecek lembut, bedeser, surut mengenjek, nglangkah maju, nglangkah mundur, srisig.

2. Gerak maknawi. Gerak maknawi adalah gerak yang mengandung arti yang jelas. Gerak maknawi yang terdapat pada Tari Petuk adalah Nyakep yang berarti sebagai ungkapan terima kasih. Sudah merupakan suatu kepastian bahwa gerak-gerak maknawi baru bernilai sebagai gerak tari apabila telah mengalami stirilisasi dan distorsi, yaitu gerak tersebut telah mengalami perubahan untuk dijadikan gerak tari.

\section{Watak Gerak}

Watak gerak terbagi menjadi dua yaitu watak gerak Feminim dan watak gerak Maskulin. Gerak yang mempunyai watak gerak Feminin biasanya untuk tari putri. Sedangkan gerak yang mempunyai watak Maskulin biasanya untuk tari putra. Watak gerak yang ada pada Tari Petuk adalah maskulin karena gerakannya yang lincah serta gerakannya yang kuat dan keras.

\section{Bentuk Pertunjukan Tari Petuk di Desa Sade Kabupaten Lombok Tengah}

Bentuk pertunjukan terdiri dari pendukung Tari Petuk, iringan Tari Petuk, kostum/busana Tari Petuk, properti Tari Petuk, tata rias Tari Petuk, lighting atau tata lampu dan tempat pertunjukan:

1. Pendukung Tari Petuk. Sebuah tarian tidak dapat terlepas dari pemusik dan penari. Jumlah pemusik terdiri dari 6 orang sedangkan penari Tari Petuk terdiri dari 1 atau 2 orang anak laki-laki. Seiring berjalannya waktu, berdasarkan pengamatan peneliti Tari Petuk kini dimainkan oleh penari laki-laki dewasa atau remaja. Hal ini dikarenakan Tari Petuk lebih kepada fungsi penyambutan.

2. Musik iringan Tari Petuk. Musik dalam tari dapat digunakan sebagai iringin ilustrasi atau pembentuk suasana. Alat musik 
yang digunakan dalam Tari Petuk terdiri dari Suling, Rincik, Gong, Gendang Kecil, Petuk dan Trompong.

3. Kostum/busana Tari Petuk. Busana tidak hanya digunakan untuk melindungi tubuh secara fisik, namun busana juga dikembangkan sebagai alat untuk memenuhi kebutuhan budaya yang berkaitan erat dengan nilainilai budaya, adat istiadat serta kaidah-kaidah keagamaan. Busana Tari Petuk antara lain Sarung Hitam, Baju Kaos Hitam, Sapu' Hitam, dan Dodot. Namun seiring berjalannya waktu kostum Tari Petuk di kreasikan menjadi sebagai berikut: a) kostum bagian kepala, b) kostum bagian tubuh

4. Properti Tari Petuk. Properti adalah segala peralatan yang digunakan atau dimainkan oleh seorang penari pada waktu menari, seperti berbagai bentuk senjata yang digunakan untuk menari, ataupun aksesoris yang digunakan penari dalam menari. Pada Tari Petuk tidak membawa properti sebagai penunjang tari.

5. Tata rias Tari Petuk. Tata rias merupakan cara atau usaha seseorang untuk mempercantik diri khususnya pada wajah. Tata rias dalam seni pertunjukan diperlukan untuk menggambarkan atau menentukan watak di atas pentas. Tata rias yang digunakan dalam Tari Petuk biasa-biasa saja atau tidak menggunakan bedak. Namun seiring berjalannya waktu riasan Tari Petuk dikreasikan untuk menambah nilai humor dalam tarian.

6. Lighting atau tata lampu. Tata lampu di dalam pertunjukan tari tidak hanya sebagai penerang saja akan tetapi berfungsi sebagai pencipta suasana dan efek dramatik, memperjelas kostum dan tata rias yang dikenakan oleh penari. Pada Tari Petuk tidak menggunakan penerang atau lighting karena biasanya tarian ini dipentaskan pada siang hari.

7. Tempat pertunjukan. Dalam suatu pertunjukan apapun bentuknya, selalu memerlukan tempat untuk menyelenggarakan pertunjukan. Dalam pementasan Tari Petuk di Desa Sade biasanya tidak menggunakan panggung khusus, karena para penari menarikan tariannya di tanah lapang yang berbentuk Arena.

\section{SIMPULAN}

Komposisi gerak Tari Petuk terdiri dari : (1) Unsur-unsur gerak meliputi: gerak bagian kepala. Gerak bagian tangan, gerak bagian badan dan gerak bagian kaki, (2) Watak gerak meliputi: gerak Feminim dan gerak Maskulin, dan (3) Jenis gerak meliputi: gerak murni dan gerak maknawi. Komposisi gerak Tari Petuk berdasarkan gerak bagian tubuh meliputi: gerak bagian kepala, gerak bagian badan, gerak bagian tangan dan gerak bagian kaki. Untuk memudahkan menganalisis, maka gerak dibagi menjadi 2 yaitu gerak sebagai sikap dan gerak sebagai pelaksana. Gerak sebagai sikap meliputi 3 gerak kepala, 3 gerak tangan, 2 gerak badan dan 3 gerak kaki. Sedangkan gerak sebagai pelaksana meliputi 4 gerak kepala, 3 gerak tangan, 2 gerak badan dan 3 gerak kaki. Analisis struktur gerak Tari Petuk ditinjau dari jenis gerak terbagi menjadi 22 gerak murni dan 1 gerak maknawi. Analisi struktur gerak Tari Petuk ditinjau dari watak gerak terdiri dari gerak Maskulin. 
Bentuk penyajian kesenian Tari Petuk terdiri dari (1) Pendukung tari meliputi: pemain musik 6 orang, penari Tari Petuk 1 atau 2 orang. (2) Iringan musik meliputi: Rincik, Gendan Kecil, Gong, Petuk, Suling dan Trompong. (3) Kostum atau busana meliputi: Baj Kaos Hitam, Sarung Hitam, Sapu' Hitam dan Dodot. (4) Properti, dalam Tari Petuk tidak menggunakan properti sebagai penunjang. (5) Tata rias diodifikasi seperti riasan kucing dengan menggunka bedak tebal dan kumis buatan. (6) Lighting atau tata lampu, dalam Tari Petuk tidak menggunakan lighting atau tata lampu karena tarian ini biasanya dipentaskan pada siang hari. (7) Tempat pertunjukan, Tari Petuk kini sering dipentaskan di panggung berbentuk Tapal Kuda dan Arena.
DAFTAR PUSTAKA

Pulayakendase \& Tim YSB. (2010). Tari Tradisional Sasak. Montong Baan. Pustaka Widya.

Sepiolita, R., T., Utami, A., \& Veronika, E.,I. (2017). Ritual Mengambik Tanah dalam Upacara Tabut di Kota Bengkulu. Jurnal Seni Tari. 6(1)

Sugiyono. (2013). Metode Penelitian Kuantitatif Kualitatif dan $R \& D$. Bandung: Alfabeta.

Wulandari, R., T. (2015). Pengetahuan Koreografi Untuk Anak Usia Dini. Malang: Universitas Negeri Malang. 